\title{
Screening of Trichoderma species for Their Biological Control Potential against Sclerotium rolfsii (The Cause of Collar Rot of Chickpea)
}

\author{
Radhika S. Desai ${ }^{1 *}$, Pankaj K. Ambhore ${ }^{2}$ and Mayuri M. Choudhary ${ }^{3}$ \\ ${ }^{1}$ Department of plant Biotechnology, ${ }^{2}$ Department of Plant Pathology, ${ }^{3}$ Department of Food \\ Chemistry \& Nutrition, SDMVM's College of Food Technology, GeoraiTanda, Paithan Road, \\ Aurangabad (M.S.) - 431001, India \\ *Corresponding author
}

\section{A B S T R A C T}

\begin{tabular}{|l|}
\hline K e y w o r d s \\
$\begin{array}{l}\text { Antagonism, Biological } \\
\text { control, Collar rot of } \\
\text { chickpea, Sclerotium } \\
\text { rolfsii, Trichoderma spp }\end{array}$ \\
\hline Article Info \\
\hline $\begin{array}{l}\text { Accepted: } \\
\text { 20 August } 2018 \\
\text { Available Online: } \\
\text { 10 September } 2018\end{array}$ \\
\hline
\end{tabular}

In the present study in-vitro antagonistic effect of four species of Trichoderma. T. harzianum (FCBP-732), T.viridi (FCBP-1123), T. koningii (FCBP-951), T. aureoviridie (FCBP-691) was studied (assessed) against a destructive soil-borne plant pathogen Sclerotium rolfsii Trichoderma species were screened by dual culture method. In this method antagonistic and pathogenic fungi were grown side by side on the growth media (i.e., potato dextrose agar) in the same petridish. Trichoderma shows antagonistic effect against sclerotia species resulting up to $100-95 \%$ reduction in its growth T.harzianum showed the best (results) antagonistic effect followed by Trichoderma viridi causing 95$90 \%$ reduction in pathogen growth. The percentage reduction in number of sclerotia of S.rolfsii is due to the interaction with different Trichoderma spp. was also recorded the present study showed that $T$. harzianum has the best antagonistic result against S.rolfsii followed by $T$. viridi

\section{Introduction}

Sclerotia rolfsii is a soil-borne pathogen in warm and most climate which attacks nearly 500 species of plant. The first report of $S$. rolfsii from Pakistan was given by Ahmed et al., (1984) on maize (Zea mays L). Biocontrol of plant pathogen can by hyper parasitizing possibilities of antagonistic on pathogenic fungi Bio-control agent may create competition against pathogens and may induce resistance in plant by producing differenthydrolytic enzymes. Bosah et al., (2010) reported that chinase and $\beta-1,3$ glucan. The use of organism as biological control agents has provided a very appealing substitute and less dangerous method for plant disease management. Bio-control of plant pathogens is a potential non chemical means for plant disease management and can serve as a substitute for costly chemical treatment are known to be extremely efficient against various pathogenic fungi Yaqub and Saleem (2010). The aim of the current investigation four Trichoderma species for Bio-control of $S$. rolfsii. 


\section{Materials and Methods}

The present study Screening of "Trichoderma species for their biological control potential against Sclerotium rolfsii (the cause of collar rot of chickpea)" carried out at Department of Plant Biotechnology SDMVM's College of Agricultural Biotechnology, Georai Tanda, Paithan Road, Aurangabad (M.S.), 431001, during Nov -2017 to Jan -2018, with objects to Culture of target fungus S.rolfsii was procured form Biofertilizer and Biopesticides for four species of Trichoderma namely $T$. harzianum (FCBP-732), T. viridi (FCBP-1123),

T. koningii (FCBP-951), T. aureoviridie (FCBP-691). Individual colonies of each species were sub cultured on malt extract agar medium and stored in refrigerator at $4^{0} \mathrm{C}$.

\section{Antagonistic activity}

Four different species of Trichoderma were tested for in vitro antagonistic activity against the target pathogen by using the dual culture method Javed et al., (2014).

Malt extract agar supplemented with streptomycin were autoclaved and poured in sterilized petriplates and inoculated with $2 \mathrm{~mm}$ plugs fungi with the help of cork borer one isolate of Trichoderma species and S. rolsfii were placed simultaneously on opposite sides of each petriplate $5 \mathrm{~cm}$ part.

In control treatment only the pathogenic fungus was inoculated plates were incubated at $27^{0} \mathrm{C}$ for 5 days, five replicates of each treatment were made and colony diameter of both the fungal species in a petriplate was recorded after 5 days of incubation.

The colony diameter in each plate was measured and average was taken percentage inhibition of mycelia growth of S.rolfsii in the presence of Trichoderma spp. was measured.
Control - Treatment

Growth inhibition $(\%)=----------------~$
Control

Where control $=$ Radial growth $(\mathrm{mm})$ of S.rolfsii in

Treatment $=$ Radial growth $(\mathrm{mm})$ of $S$. rolfsiiin the presence of a Trichoderma species

Reduction in number of S.rolfsii was determine according to the method of Mishra (2010) by counting the number of Sclerotia in treated and control plates.

\section{Statistical analysis}

The experiment was performed in completely randomized block design with five replicates the data from different treatments were analyzed through analysis of variance followed by turkeys HSD test $(\mathrm{P} \leq 0.5)$ using computer software statistics

\section{Results and Discussion}

Antagonistic activity of four different species of Trichoderma was shown with measuring the pathogen growth by dual culture techniques. The growth of S.rolfsii restricted by antagonistic strains of Trichoderma spp. and showed significance inhibition. In the present study four Trichoderma spp. were selected for screening against S.rolfsii of chickpea.

It was observed that $T$. harzianum showed excellent antagonistic activity against pathogen with $100-95 \%$ of inhibition besides T. viridi reduces the growth by $95-90 \%$ followed by $T$. koningii $83-83 \%$ lastly by $\mathrm{T}$. aureoviridi $65-60 \%$ in dual culture method over control. Data illustrated showed that $T$. viridii and T. harzainum showed the highest $\%$ of reduction of sclerotial bodies in experimental plates (Fig. 1). 
Fig.1 Growth inhibition of S.rolfsii due to interactions with different Trichoderma species.

Vertical bars show standard errors of means of four replicates
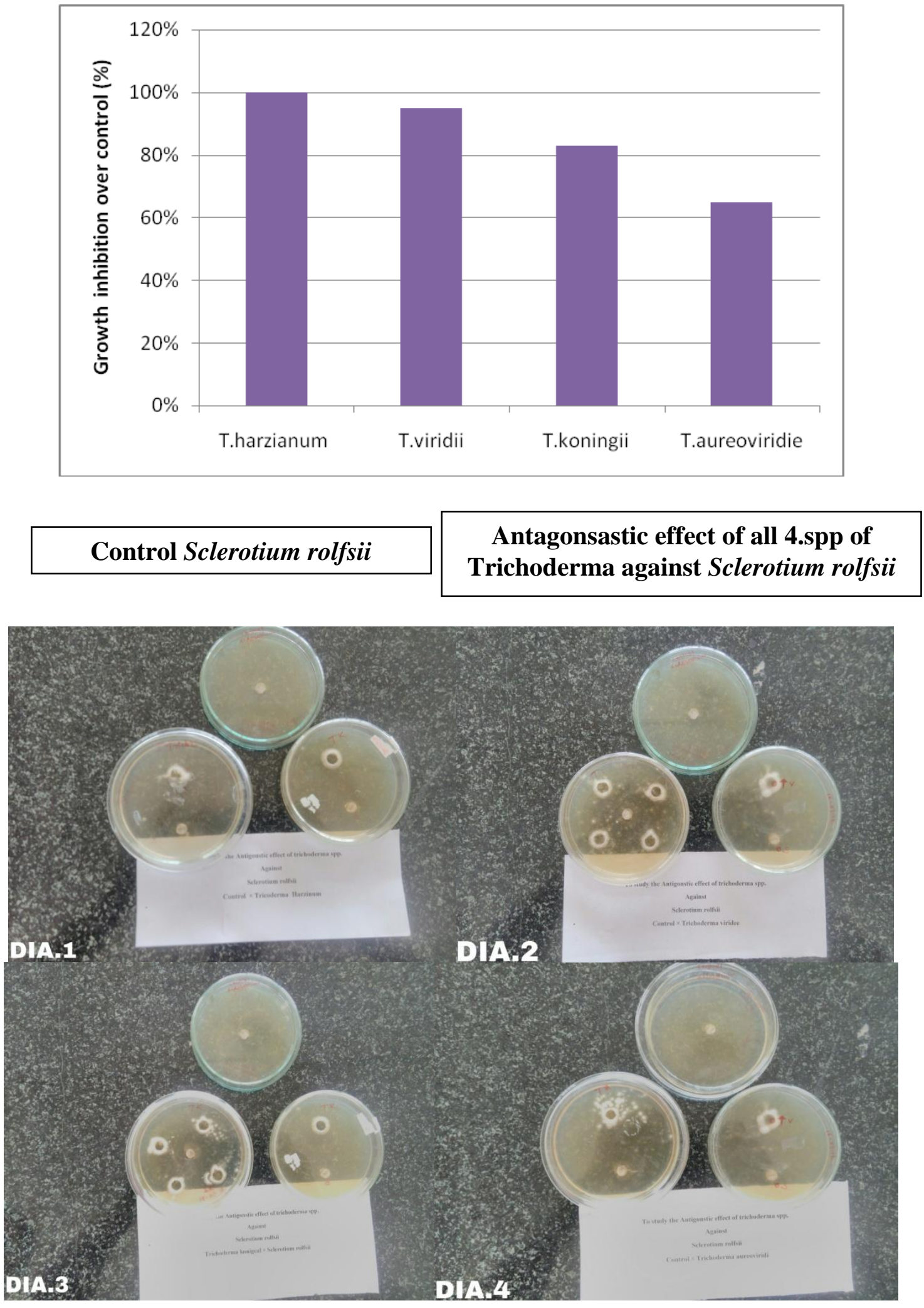


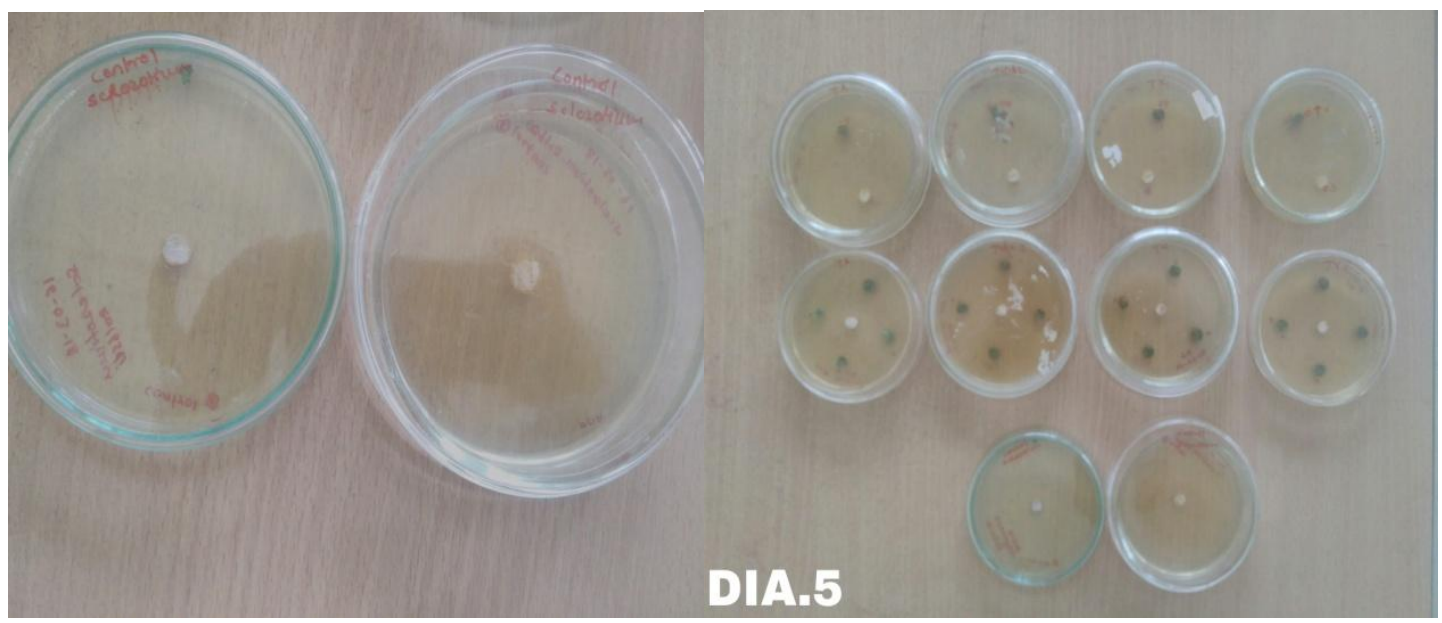

Trichoderma species are mycoparsites Doley and Jite (2012) and are commonly used as antimicrobial agents. Several Trichoderma species are antagonistic to other plant pathogenic fungi Bosah et al., (2010). The competition, antibiosis, myco-parasitism, induce resistance and inactivation of pathogens compound such as enzymes are some of their different ways of parasitism to other plant pathogenic fungi. The antimicrobial activity of Trichoderma against some plant pathogenic fungi Mishra et al., (2011) has been suggested as one of the significance procedure.

Previously different Trichoderma species have been recorded to produce a variety of antibiotics such as Trichodermin, Trichodermol, Harizianum A, and Harizianolide Mishra (2010) which may help in decreasing ill effects of dangerous pathogens. Many scientists revelead anagonistic activity of Trichoderma species against many phaytopathogen (Howell (2002), mishra (2010), bosah et al., (2010), mishra et al., (2011), Doley and Jite (2012)) besides, dual culture techniques in widely used in antagonsitc studies by different scientist Khattabi et al., (2004) and Rekha et al., (2012). In dual culture technique a clear zone of inhibition and antagonist. The degree of inhibition varied from one species to another. The isolates of different Trichoderma species to management S.rolfsii have been revealed to vary in their potential Omar and Maha (2010). Trichoderma harzianum exhibited $100 \%$ reduction in growth of the pathogen formation of inhibition zone at the contact between Trichoderma and S. rolfsii could be explained on the basis of production of volatile and non-volatile metabolites as well as production of extracelluar hydrolytic enzymes by Trichoderma EL-Katatny (2001), Aly et al., (2007) observed bio-control activity of Trichoderma spp. against Macrophomina phaseolina in vitro and mishra et al., (2011) revealed that Trichoderma species are typical inhabitant of rhizosphere and manage many soil-borne plant disease caused by fungi Rekha et al., (2012) studied that culture filtrates of $T$. harzianum restrict formation of zoospore of germ tube is mycelial growth of $S$. rolfsii. In another studies, culture filtrate of $T$. viride inhibited the mycellal growth of Sclerotinia sclerotiorum due to production of antibiotic like substance Kapil and Kapoor (2005), Kartikeyan et al., (2006) who confirmed culture filterates of $T$. viridi suppressing the development of the pathogen growth and sclerotial germination.

T. viride restricted the development of sclerotial germination parasitized mycelium 
of S.rolfsii in dual culture assays noticed by Kapoor (2008) chitinase of Trichoderma spp. deteriorates the chitin in the cell walls of S.rolfsii helps in penetration of S.rolfsii mycelium (Doley and Jite, 2012).

In recent studies toxic fungistatic metabolites may be produced by the Trichoderma species against S.rolfsii several researchers studied different species of Trichoderma as the best antimicrobial for growth inhibition of several plant pathogen related to seeds and soil Mukherjee and Tripathi (2000) yaqub and shazad (2005), barakat et al., (2006), Mishra et al., (2011). Currently the facts regarding the antagonistic potential of $T$. harzanium and $T$. viridi species had significant potential and effective antagonism against $S$.rolfsii.

\section{References}

Ahmed Y, Mirza MS, Aslam M, 1984. Sclerotium rolfsii on maize. FAO Plant Prot. Bull., 32: 147.

Aly A, Abdel-Sattar MA, Omar MR, AbdElsalam KA, 2007.Differential antagonism of Trichoderma sp. against Macrophomina phaseolina. J. Plant Prot. Res., 47:91-107.

Barakat M, Fadel A, Mohammed S, Mohammad A, 2007. Biological Control of Rhizoctonia solani by Indigenous Trichoderma spp. Isolates from Palestine. Hebron Uni. Res. J., 3: $1-15$.

Bosah O, Igeleke CA, Omorusi VI, 2010. In vitro microbial control of pathogenic Sclerotium rolfsii. Int. J.Agric. Biol., 12:474-476.

Doley K, Jite PK, 2012. In vitro efficacy of Trichoderma viride against Sclerotium rolfsii and Macrophomina phaseolina. Not. Sci. Biol., 4:39-44.

El-Katatny MH, Gudelj M, Robra KH, Elnaghy MA, Gubitz GM, 2001. Characterization of a chitinase and anendo-b-1, 3-glucanase from

Trichoderma harzianum RifaiT24

involved in control of the phytopathogen Sclerotium rolfsii. Appl.Microbiol.Biotechnol., 56: 137143

Howell CR, 2002. Cotton seedling preemergence damping-offincited by Rhizopus oryzae and Pythium spp. and its biological control with Trichoderma spp. Phytopathology, 92:177-180.

Javaid A, Laiba A, Anila B, Amna S, 2014. In vitro screening of Trichoderma species against Macrophomina phaseolina and Fusarium oxysporum f. sp. lycopersici. Pak. Phytopathol., 26:37-41.

Kapil R, Kapoor AS, 2005. Management of white rot of pea incited by (Sclerotinias clerotiorum) using Trichoderma spp. and biopesticides. Indian Phytopathol., 58:10-16.

Karthikeyan M, Radhika K, Mathiyazhagan R, Bhaskaran R, Samiyappan R, Velazhahan R, 2006. Induction of phenolics and defense related enzymes in coconut (Cocos nucifera L.) root treated with biocontrol agents. Braz. J. Plant Physiol., 18: 367-377.

Khattabi N, Brahim E, Latifa L, Abdallah O, 2004. Antagonistic activity of Trichoderma isolates against Sclerotium rolfsii: screening of efficient isolates from Moroccosoils for biological control. Indian Phytopathol., 58: 22-32.

Mishra BK, Rohit KM, Mishra RC, Amit KT, Ramesh SY, Anupam D, 2011. Biocontrol efficacy of Trichoderma viride isolated against fungal plant pathogens causing disease in Vignaradiata. Arch. Appl. Sci. Res., 3: 361-369.

Mishra VK, 2010. In vitro antagonism of Trichoderma species against Pythium aphanidermatum. J. Phytopathol., 2: 28-35.

Mukherjee S, Tripathi HS, 2000. 
Biologicaland chemical control of wilt complex of French bean.J. Mycol. Plant Pathol., 30: 380-385.

Omar M, Maha A, 2010. Antagonistic Activity and Production of Antifungal Compound(s) from Selected Trichoderma spp. J. Edu. Sci., 23: 123130.

Omorusi VI, Evueh GA, Ogbebor NO, 2007. In vitro assessment of biological control of whiterootrot of rubber (Heveabrasiliensis) by antagonistic fungi. Phytopathol. Mediterr. 43: 332340.

Rekha D, Patil MB, Shridhar S, Swamy P,
Rajini K, Gamanagatti B, 2012. In vitro screening of native Trichoderma isolates against Sclerotium rolfsii causing collar rot of ground nut. Pak. J.Bot., 34: 117-120.

Yaqub F, Shahzad S, 2010. Competitive colonization of wheat straw by Trichoderma species and Sclerotium rolfsii. Pak. J. Bot., 42: 1983-1989.

Yaqub F, Shahzad S, 2005. Pathogenicity of Sclerotium rolfsii on different crops and effect of inoculum density on colonization of mungbean and sunflower. Pak. J. Bot., 37:175-180.

\section{How to cite this article:}

Radhika S. Desai, Pankaj K. Ambhore and Mayuri M. Choudhary. 2018. Screening of Trichoderma species for Their Biological Control Potential against Sclerotium rolfsii (The Cause of Collar Rot of Chickpea). Int.J.Curr.Microbiol.App.Sci. 7(09): 3126-3131. doi: https://doi.org/10.20546/ijcmas.2018.709.389 